\title{
The diversity, abundance and seasonal distribution of planktonic microcrustacean (Copepoda, Cladocera) in Kayalıköy Reservoir (Kırklareli/Turkey)
}

\section{Kayalıköy Barajı’nın (Kırklareli/Türkiye) planktonik mikrokrustase (Copepoda, Cladocera) tür çeşitliliğĭ, bolluğu ve mevsimsel dağılımı}

\author{
Hüseyin Güher ${ }^{1^{\star}}$ • Burak Öterler ${ }^{2}$ \\ ${ }^{1}$ Trakya University Faculty of Science, Department of Biology, 22030, Edirne, Turkey \\ ${ }^{2}$ Trakya University Faculty of Science, Department of Biology, 22030, Edirne, Turkey
}

https://orcid.org/0000-0001-6206-0912

https://orcid.org/0000-0002-9064-1666

*Corresponding author: huseying@trakya.edu.tr

Received date: 23.12 .2019

Accepted date: 14.08 .2020

\section{How to cite this paper:}

Güher, H. \& Öterler, B. (2021). The diversity, abundance and seasonal distribution of planktonic microcrustacean (Copepoda, Cladocera) in Kayalıköy

Reservoir (Kırklareli/Turkey). Ege Journal of Fisheries and Aquatic Sciences, 38(1), 21-29. DOI: 10.12714/egejas.38.1.03

Abstract: This study was carried out to determine the diversity, abundance and seasonal distribution of planktonic microcrustaceans (Cladocera, Copepoda) in Kayalıköy Reservoir. Cladocera and Copepoda samples were collected from May 2018 to April 2019 at three stations in the reservoir and some environmental parameters were measured. The qualitative evaluation of the samples revealed presence of 40 species, 24 from Cladocera and 16 from Copepoda, in the reservoir. The quantitative evaluation of the samples showed that $52690 \mathrm{ind} . / \mathrm{m}^{3}$ zooplankton on average was found in the reservoir. The most common species in the reservoir were Daphnia cucullata, D. Iongispina, D. pulex, Bosmina longirostris and Chydorus sphaericus from Cladocera, and Arctodiaptomus wierzejskii, Acanthocyclops robustus and Thermocyclops crassus from Copepoda. According to the water quality standards, the measured values of water temperature, dissolved oxygen, sulfate, salinity and chloride indicated the first quality of water, while the light permeability, nitritenitrogen, nitrate-nitrogen, ortho-phosphate and chlorophyll-a values indicated the second and third quality of water levels. According to these results, we conclude that Kayalıköy Reservoir has a mesotrophic character in terms of the microcrustacean fauna and the physicochemical parameters.

Keywords: Microcrustacean, diversity, seasonal distribution, water quality, reservoir

Öz: Bu çalışma, Kayalıköy Baraj Gölü'nün planktonik microcrustacean (Cladocera, Copepoda) çeşitliliğini, bolluğunu ve mevsimsel dağlımını belirlemek amacıyla Mayıs 2018 ile Nisan 2019 arasında yapıImıştır. Cladocera ve Copepoda örnekleri baraj gölünde belirlenen üç istasyondan toplanmış olup, bu organizmaları etkileyen bazı çevresel parametreler de ölçülmüştür. Alınan örneklerin nitel değerlendirilmesi sonucunda Cladocera'dan 24, Copepoda'dan 16 olmak üzere 40 tür belirlenmiştir. Örneklerin nicel değerlendirmesi, baraj gölünde yıllık ortalama 52690 birey $/ \mathrm{m}^{3}$ planktonik microcrustacean olduğunu göstermiştir. Baraj gölündeki en yaygın türler, Cladocera'dan Daphnia cucullata, D. Iongispina, D. pulex, Bosmina longirostris ve Chydorus sphaericus; Copepoda'dan Arctodiaptomus wierzejskii, Acanthocyclops robustus ve Thermocyclops crassus türleridir. Ölçülen su sıcaklğı, çözünmüş oksijen, sülfat, tuzluluk ve klor değerleri su kalitesi standartlarına göre birinci kalite, Işık geçirgenliği, nitrit ve nitrat azotu, ortofosfat ve klorofil-a değerlerine göre ise ikinci ve üçüncü kalite su değerinde olduğunu göstermektedir. Bu sonuçlara göre, Kayalıköy Baraj Gölü'nün planktonik microcrustacean faunası ve fizikokimyasal parametreler açısından mezotrofik karakterde olduğu tespit edilmiştir.

Anahtar kelimeler: Mikrokrustase, çeşitlilik, mevsimsel dağııım, su kalitesi, rezervuar

\section{INTRODUCTION}

Reservoirs provide favourable environments for the development of zooplankton communities while some biological communities are formed in short periods after impoundment. Various factors generally contribute to the establishment of zooplankton communities in a reservoir such as good water quality, the presence of nutrients, physicochemical factors of water, the presence of phytoplankton, the hydrological properties and the aging of the reservoir (Rocha et al., 1999). Once established, the zooplankton community generally influences energy flow through the classical food chain, food cycle, and community population dynamics in the reservoir ecosystem.
Zooplanktonic organisms that occupy the second trophic level in the food chain in freshwater ecosystems are an important food source for many vertebrate and invertebrate animals (Berzins and Pejler, 1987). Also, studies showed that some zooplankton species are generally considered indicators of water quality, trophic status, and pollution (Parmar et al., 2016).

The zooplankton community of freshwater ecosystems generally consists of Protozoa, Rotifera, and planktonic microcrustacean (Rocha et al., 1999). Cladocera and Copepoda are widely distributed planktonic microcrustacean that predominantly occur in freshwater. These taxa include littoral, pelagic and benthic species, which perform key roles 
in the food web. The changes in population density, species richness and community structure of microcrustaceans (Cladocera and Copepoda) are mostly affected by physicochemical conditions and biological factors of the freshwater in which they live (Patra et al., 2011).

The abundance and species composition of zooplankton give information the trophic level in aquatic systems. The abundance of zooplanktonic organisms in a waterbody is closely related to physicochemical features and nutrient amounts in the water resources (Berzins and Pejler, 1987). Therefore, studies on seasonal variations of the planktonic microcrustaceans in aquatic ecosystems are very important. Several studies have been carried out to examine the distribution and diversity of microcrustaceans (Cladocera and Copepoda) in the inland waters of Turkey. The first study on the zooplankton biodiversity was reported at the beginning of the 1900's. (Ustaoğlu, 2015). More recently, Saler and Alış (2014), Ulgu and Bozkurt (2015), Güher and Çolak (2015), Güher (2019) and Dorak et al., (2019) performed studies on planktonic microcrustacean in different Turkish reservoirs, but the distribution and diversity of planktonic microcrustacean (Cladocera and Copepoda) of Kayalıköy Reservoir have not been studied so far.

The present study focused on planktonic microcrustacean composition in Kayalıköy Reservoir with special reference to their densities, abundance, and seasonal distributions, all of which are determining the water quality. Some environmental parameters of the reservoir were also investigated.

\section{MATERIALS AND METHODS}

Kayalıköy Reservoir was built between the years 1981 and 1986 for irrigation and flood control on Teke Stream and was named from Kayalı village to the west of the reservoir. The reservoir is located $12 \mathrm{~km}$ to the west of Kırklareli city center $\left(41^{\circ} 44^{\prime} 4200^{\prime} \mathrm{N}, 263^{\circ} 53^{\prime \prime} 414^{\prime} \mathrm{\prime} \mathrm{E}\right)$. Because it is surrounded by rock formations, both the lake and the littoral zone lack water plants. The volume of the reservoir is about $144.2 \mathrm{hm}^{3}$ and the surface area is $10.20 \mathrm{~km}^{2}$. Although the reservoir is fed mainly by the Teke Stream, it is also fed by other creeks in the basin and by rainfall. In addition to its role in irrigation and flood control, it also provides drinking and domestic water of Edirne.

The samples were collected monthly, from May 2018 to April 2019, at three stations in the reservoir. The first sampling station is located in the western part of the reservoir where Teke Stream feeds the reservoir $\left(41^{\circ} 49^{\prime} 30.5^{\prime \prime} \mathrm{N}\right.$ $\left.27^{\circ} 06^{\prime} 30.3^{\prime \prime} \mathrm{E}\right)$. The second sampling station is located in the middle of the reservoir $\left(41^{\circ} 47^{\prime} 28.3^{\prime \prime} \mathrm{N} 27^{\circ} 08^{\prime} 07.3^{\prime \prime} \mathrm{E}\right)$ and the third sampling station is located in the eastern branch of the reservoir $\left(41^{\circ} 48^{\prime} 06.0^{\prime \prime} \mathrm{N} 27^{\circ} 09^{\prime} 13.1 " \mathrm{E}\right)$ (Figure 1).

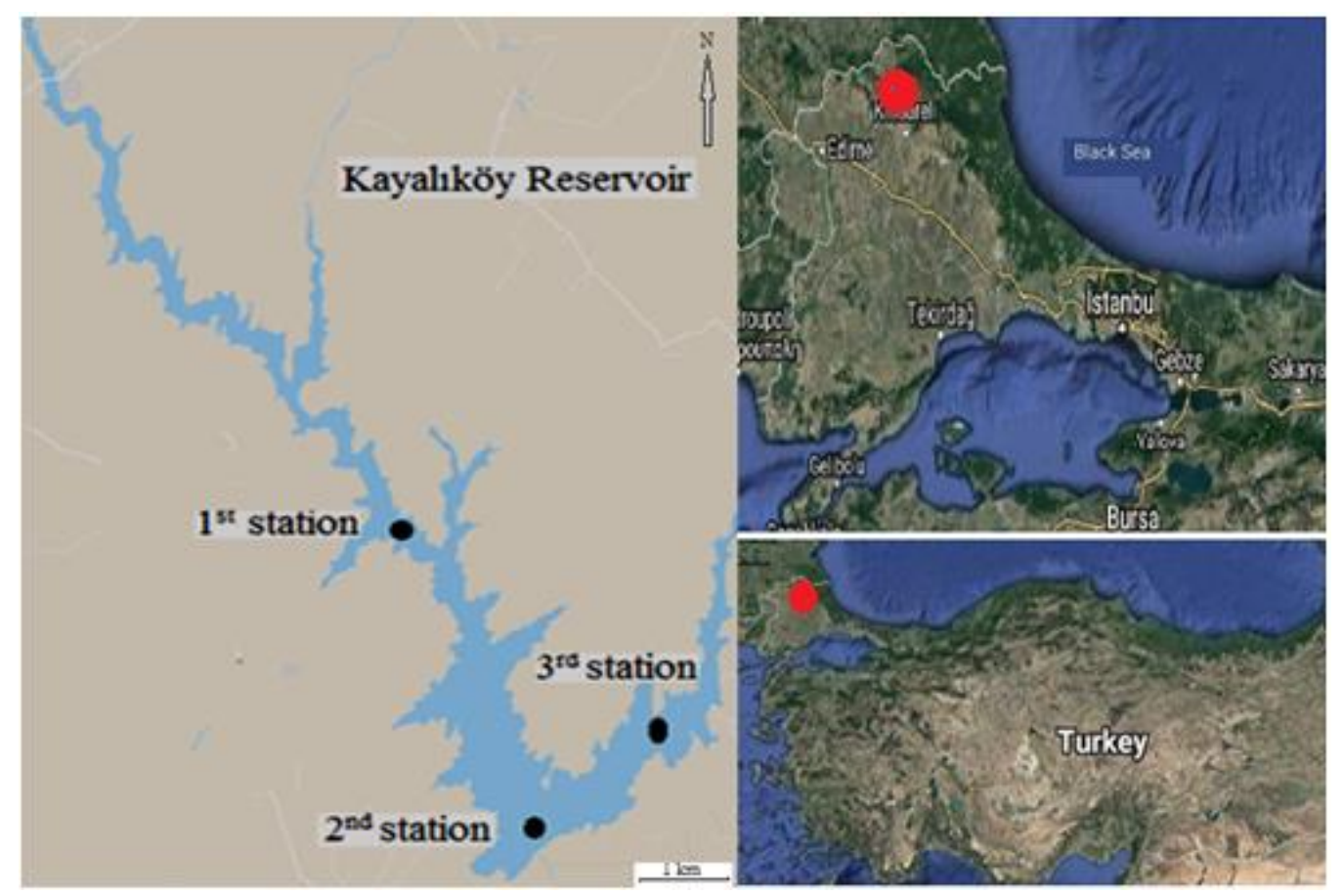

Figure 1. Location of Kayalıköy Reservoir and the sampling stations

Microcrustacean samples were collected with an Hensen type plankton net (mesh size $55 \mu$, mouth diameter $15 \mathrm{~cm}$, length $75 \mathrm{~cm}$ ) vertically up to the surface from the bottom point (10 $\mathrm{m}$ deeply) and horizontally. The water samples were taken with Ruttner water sample bottles from about 15 to 20 $\mathrm{cm}$ below the water surface. Some physicochemical parameters (water temperature, dissolved oxygen, $\mathrm{pH}$, conductivity, and salinity) were measured on site simultaneously by using Orion Star S/N 610541. The light permeability of the reservoir was measured using a Secchi 
disk. The analyses were made in laboratories of the Trakya University Technology Research Development Application and Research Centre. The analyses of the ions were performed by Metrohm lon Chromatography System using EPA 300.1 method. Metal analyses were read on the Agilent Technologies 7700 ICP-MS System using EPA 200.7 and EPA 200.8 methods (EPA, 2001).

Plankton samples taken from the reservoir were immediately preserved in $4 \%$ formaldehyde in field and then and brought to the laboratory for further analyses. In the laboratory, samples were identified at the species level according to Flössner (1972), Smirnov (1974), Margaritora (1983), Korinek (1987) and Beldzki and Raybok (2016) for Cladocera, and Dussart (1967, 1969), Dussart and Defaye (2002, 2006), Kiefer (1978), Apostolov and Marinov (1988) and Beldzki and Raybok (2016) for Copepoda.

The counting of the samples was made according to Lackey (1938) using an Olympus inverted microscope and was calculated using the following formula of Lackey (1938). Densities are presented as the number of individuals per cubic meter (ind. $/ \mathrm{m}^{3}$ ).

\section{$\mathrm{N}=\mathrm{n} \times \mathrm{v} / \mathrm{V}$}

where,

$\mathrm{N}=$ Total number of organisms $/ \mathrm{m}^{3}$ of water filtered,

$\mathrm{n}=$ Number of zooplankton counted in $5 \mathrm{ml}$ plankton sample,

$\mathrm{v}=$ Volume of concentrate plankton sample $(\mathrm{ml})$,

$\mathrm{V}=$ Volume of total water filtered through $\left(\mathrm{m}^{3}\right)$

Spearman's correlation was used to determine the relationship of Cladocera and Copepoda groups with each other and with environmental parameters (Krebs, 1999). Shannon-Weaver index, Margalef index and Simpson's diversity index were used to determine the species diversity of planktonic microcrustaceans (Shannon and Weaver, 1949; Margalef, 1958). Bray-Curtis similarity index was used to examine the similarities of the sampling the months and the seasons according to diversity and abundance of Cladocera and Copepoda species (Jaccard, 1912).

\section{RESULTS AND DISCUSSION}

\section{Physicochemical variables}

The minimum and maximum values of the physicochemical parameters measured in the reservoir were given in Table 1. Variations in these environmental parameters according to the sampling stations and months were given in Figure 2.

The water temperature values fluctuated during the study period ranged from $3.33{ }^{\circ} \mathrm{C}$ to $30{ }^{\circ} \mathrm{C}$. The maximum water temperature was recorded in August and the minimum in January (Table 1 and Figure 2). The lowest total planktonic microcrustacean abundance was found in winter (15130 ind. $\left./ \mathrm{m}^{3}\right)$. Because temperature is the most important factor affecting the amount of nutrients in freshwater (Geller and Müller, 1981).

The dissolved oxygen values ranged from 8.49 to 13.76 (average $10.28 \pm 1.66$ ). The maximum dissolved oxygen was recorded in April and the minimum in July (Table 1 and Figure 2). In freshwater ecosystems, the least dissolved oxygen amount for aquatic life may not be less than $5.0 \mathrm{mg} / \mathrm{L}$. With the oxygen content falling below $5 \mathrm{mg} / \mathrm{L}$, living will be affected, and some species will be damaged (Kaya and Altındağ, 2007).

The light permeability in the reservoir was measured between $36.67-186.67 \mathrm{~cm}$. The maximum light permeability was recorded in May and the minimum in January (Table 1 and Figure 2). The lake is considered as eutrophic if the measured light permeability is between 0.8 and $1.5 \mathrm{~m}$, mesotrophic if it is between 1.4 and $2.4 \mathrm{~m}$, and oligotrophic if it is between 3.6 and $5.9 \mathrm{~m}$ (Ryding and Rast, 1989). According to this classification based on light permeability, Kayalıköy Reservoir can be categorized as eutrophic since the measured average light permeability is $94.24 \pm 39.34 \mathrm{~cm}$.

The $\mathrm{pH}$ values fluctuated during the study period from 6.36 to 9.48 (average $8.44 \pm 0.79$ ) (Table 1 and Figure 2). The $\mathrm{pH}$ value of the reservoir was moderately alkaline varying from 7.5 to 8.2 (Berzins and Pejler, 1987). According to the mean $\mathrm{pH}$ values, Kayalıköy Reservoir is as an alkaline water bearing reservoir.

Table 1. The measured physicochemical parameters and their minimum, maximum and average values ("below limit of detection)

\begin{tabular}{lllll}
\hline & Abbreviation & Min & Max & Average \\
\hline Water temperature $\left({ }^{\circ} \mathrm{C}\right)$ & $\mathrm{WT}$ & 3.33 & 30.00 & $17.14 \pm 9.06$ \\
Dissolved oxygen $(\mathrm{mg} / \mathrm{L})$ & $\mathrm{DO}$ & 8.49 & 13.76 & $10.28 \pm 1.66$ \\
Light permeability $(\mathrm{cm})$ & $\mathrm{LP}$ & 36.67 & 186.67 & $94.24 \pm 39.34$ \\
$\mathrm{pH}$ & $\mathrm{pH}$ & 6.36 & 9.48 & $8.44 \pm 0.79$ \\
Conductivity $(\mu \mathrm{S} \mathrm{cm} / \mathrm{L})$ & $\mathrm{EC}$ & 177.23 & 319.77 & $249.94 \pm 41.91$ \\
Nitrite nitrogen $(\mathrm{mg} / \mathrm{L})$ & $\mathrm{NO}_{2}-\mathrm{N}$ & $*$ & 0.13 & $0.05 \pm 0.05$ \\
Nitrate nitrogen $(\mathrm{mg} / \mathrm{L})$ & $\mathrm{NO}_{3}-\mathrm{N}$ & 0.06 & 4.97 & $2.46 \pm 1.67$ \\
Ortho-phosphate $(\mathrm{mg} / \mathrm{L})$ & $\mathrm{O}-\mathrm{PO}_{4}$ & $*$ & 0.84 & $0.13 \pm 0.24$ \\
Sulfate $(\mathrm{mg} / \mathrm{L})$ & $\mathrm{SO}_{4}$ & 14.67 & 17.08 & $16.00 \pm 0.78$ \\
Salinity $(\% \circ)$ & $\mathrm{Sal}$ & 0.14 & 0.20 & $0.17 \pm 0.02$ \\
Chloride $(\mathrm{mg} / \mathrm{L})$ & $\mathrm{Cl}$ & 0.04 & 0.34 & $0.12 \pm 0.11$ \\
Chlorophyll-a $(\mu \mathrm{g} / \mathrm{L})$ & $\mathrm{Chl}-\mathrm{a}$ & 4.33 & 23.83 & $10.71 \pm 7.00$ \\
\hline
\end{tabular}



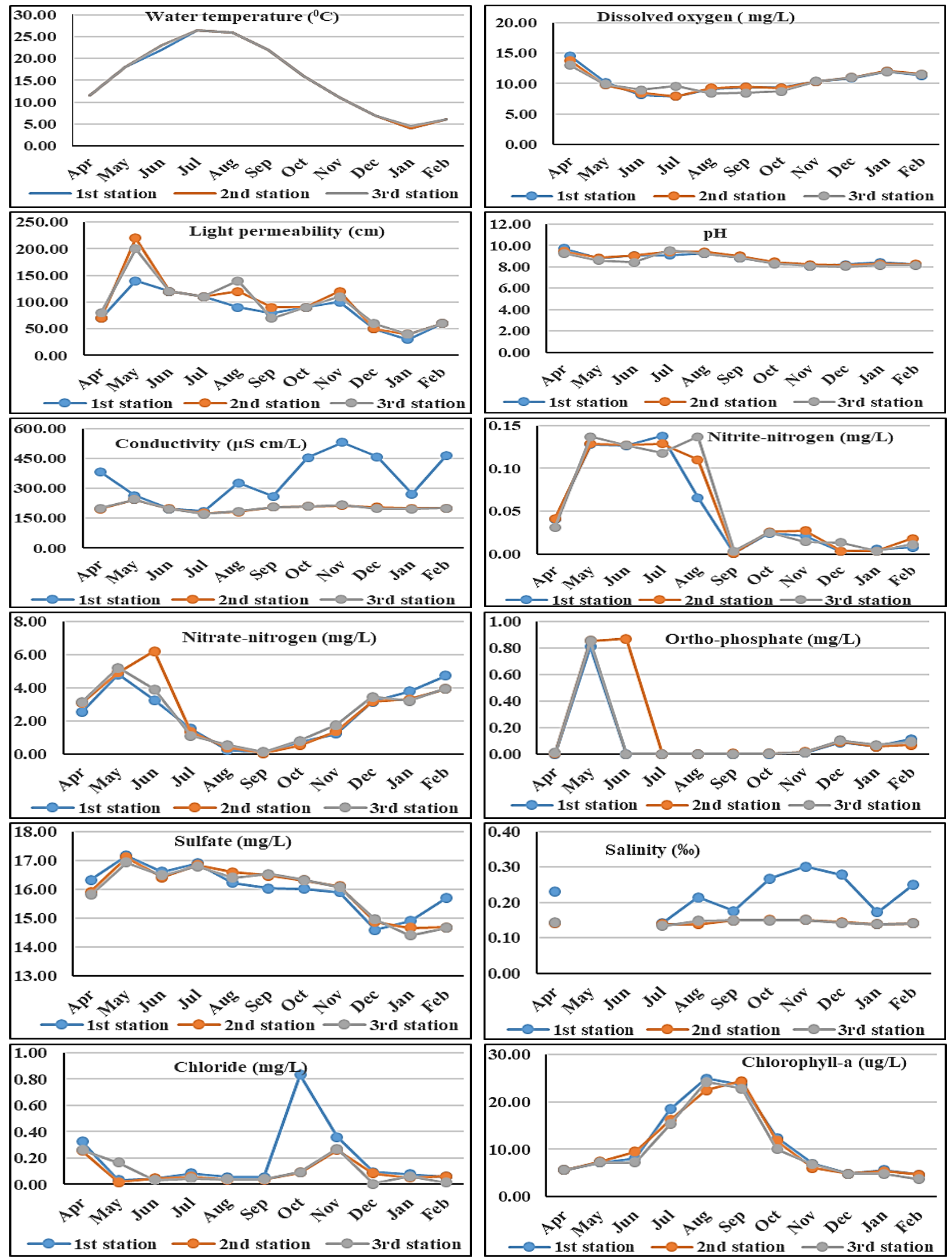

Figure 2. Variations of the physicochemical parameters according to the sampling stations and months 
During the study period in Kayalıköy Reservoir, the nitritenitrogen content was found below the limit of detection in September, while it was highest in July with $0.13 \mathrm{mg} / \mathrm{L}$ (average $0.05 \pm 0.05$ ). The nitrate-nitrogen content was measured between 0.06 to $4.97 \mathrm{mg} / \mathrm{L}$ (average $2.46 \pm 1.67$ ). The ortho-phosphate content was found below the limit of detection in July, August, and September while it was highest in May with $0.84 \mathrm{mg} / \mathrm{L}$ (average $0.13 \pm 0.29$ ) (Table 1 and Figure 2). If the total phosphorus is less than $10 \mu \mathrm{g} / \mathrm{L}$, the lake is oligotrophic, if between $10-20 \mu \mathrm{g} / \mathrm{L}$ it is mesotrophic and if it is greater than $20 \mu \mathrm{g} / \mathrm{L}$, it is eutrophic (Thomann and Mueller, 1987). For ponds and dam lakes, the total nitrogen contents are $\leq 0.35 \mathrm{mg} / \mathrm{L}$ in oligotrophic lakes, $0.35-0.65 \mathrm{mg} / \mathrm{L}$ in mesotrophic lakes, and $0.65-1.2 \mathrm{mg} / \mathrm{L}$ in eutrophic lakes (Anonymous, 2015). According to the mean phosphate and nitrite-nitrogen values, Kayalıköy Reservoir was rated as mesotrophic.

The values of chlorophyll-a fluctuated during the study from 4.33 to $23.83 \mu \mathrm{g} / \mathrm{L}$. The maximum chlorophyll-a was recorded in August and the minimum in February (Table 1 and Figure 2). For ponds and dam lakes, the amount of chlorophyll-a in oligotrophic lakes is $<3.5 \mu \mathrm{g} / \mathrm{L}$, between 3.5 $9.1 \mu \mathrm{g} / \mathrm{L}$ in mesotrophic lakes and between $9.1-25 \mu \mathrm{g} / \mathrm{L}$ in eutrophic lakes (Anonymous, 2015). The lake is considered as eutrophic if the average value of the measured chlorophylla $14.3 \mu \mathrm{g} / \mathrm{L}$; mesotrophic if it is $4.7 \mu \mathrm{g} / \mathrm{L}$ and oligotrophic if it is $1.7 \mu \mathrm{g} / \mathrm{L}$ (OECD, 1982). According to the chlorophyll-a values, Kayalıköy reservoir was rated as mesotrophic.

The comparison of the results of physicochemical analyses with National Standard for Turkish inland water revealed that water temperature $(17.14 \pm 9.06)$, the dissolved oxygen (10.28 \pm 1.66$)$, $\mathrm{pH}(8.44 \pm 0.79)$, the sulfate $(16.00 \pm$ $0.78)$, the salinity $(0.17 \pm 0.02)$ and the chloride $(0.12 \pm 0.11)$ were found at the first quality level. The light permeability $(94.24 \pm 39.34)$, the nitrite-nitrogen $(0.05 \pm 0.05)$, the nitratenitrogen $(2.46 \pm 1.67)$, the phosphate $(0.13 \pm 0.24)$ and the chlorophyll-a $(10.71 \pm 7.00)$ was found between second and third quality levels (Anonymous, 2015) (Table 1).

\section{Community structure of planktonic microcrustacean}

Plankton samples taken from the reservoir were studied qualitatively and quantitatively. As a result of the qualitative evaluation of the samples, a total of 40 microcrustacean species (24 Cladocera and 16 Copepoda) were found (Table 2). Also, Cyclopoid copepodites, Calanoid copepodites, and Nauplius were observed. Simocephalus vetulus, Alonella excisa, Alona costata, Coronatella rectangula, Oxyurella tenuicaudis and Monospilus dispar from Cladocera, and Paracyclops fimbriatus, Canthocamptus microstaphylinus and C. staphylinus from Copepoda were found in horizontal samples taken for the qualitative analysis, but they were not observed in vertical samples. (Table 2).

The maximum species diversity was recorded as, 10 species from Cladocera in September and in October and 10 species from Copepoda in May, while the least diversity was found as 3 species from Cladocera in January and 2 species from Copepoda in December, July and in August.
Table 2. The planktonic microcrustacean species in Kayalıköy Reservoir and the average values of their annual numbers per $\mathrm{m}^{3}$ ( ${ }^{*}$ These species were found in the qualitative analysis but they were not in the quantitative analysis)

\begin{tabular}{lrr}
\hline & \multicolumn{1}{c}{$\begin{array}{c}\text { Annual } \\
\text { average }\end{array}$} \\
& (ind./m³ & \multicolumn{1}{c}{$\%$} \\
\hline CLADOCERA & & \\
Diaphanosoma brachyurum (Liévin,1848) & $3800 \pm 3963$ & 14.29 \\
Daphnia pulex (Leydig, 1860) & $1371 \pm 1533$ & 5.16 \\
Daphnia cucullata (Sars, 1862) & $4295 \pm 3447$ & 16.16 \\
Daphnia galeata (Sars, 1863) & $3144 \pm 2551$ & 11.83 \\
Daphnia parvula (Fordyce, 1901) & $523 \pm 689$ & 1.97 \\
Daphnia longispina (O.F.Müller, 1876) & $4720 \pm 3389$ & 17.75 \\
Ceriodaphnia quadrangula (O.F.Müller, 1785) & $85 \pm 51$ & 0.32 \\
Moina micrura (Kurz, 1874) & $22 \pm 38$ & 0.08 \\
lyocryptus sordidus (Liévin, 1848) & $7 \pm 13$ & 0.03 \\
Bosmina longirostris (O.F.Müller, 1785) & $7709 \pm 7490$ & 29.00 \\
Pleuroxus aduncus (Jurine, 1820) & $44 \pm 77$ & 0.17 \\
Pleuroxus uncinatus (Baird,1850) & $26 \pm 26$ & 0.10 \\
Chydorus latus (Sars, 1862) & $15 \pm 26$ & 0.06 \\
Chydorus sphaericus (O.F.Müller, 1776) & $498 \pm 322$ & 1.87 \\
Alona guttata (Sars, 1862) & $17 \pm 17$ & 0.06 \\
Alona quadrangularis (O.F.Müller, 1785) & $15 \pm 26$ & 0.06 \\
Leydigia leydigi (Schödler, 1863) & $7 \pm 13$ & 0.03 \\
Leptodora kindtii (Focke, 1844) & $288 \pm 249$ & 1.08
\end{tabular}

*Simocephalus vetulus (O.F.Müller,1776)

*Alonella excisa (Fischer, 1854)

*Alona costata (Sars, 1862)

${ }^{*}$ Coronatella rectangula (Sars, 1862)

*Oxyurella tenuicaudis (Sars, 1862)

*Monospilus dispar (Sars, 1862)

Total Cladocera

$26586 \pm 16455100.00$

\section{COPEPODA}

Eudiaptomus vulgaris (Schmeil, 1898)

Eudiaptomus gracilis (Sars,1863)

$590 \pm 937 \quad 2.26$

Arctodiaptomus wierzejskii (Richard, 1888)

Arctodiaptomus (Rh.) bacillifer (Koelbel, 1885)

Eucyclops serrulatus (Fischer, 1851)

Macrocyclops albidus (Jurine, 1820)

Cyclops abyssorum (Sars, 1863)

Cyclops strenuus (Fischer, 1851)

Cyclops vicinus (Uljanin, 1875)

Acanthocyclops robustus (Sars, 1863)

Mesocyclops leuckarti (Claus, 1857)

Megacyclops viridis (Jurine, 1820

Thermocyclops crassus (Fischer, 1853)

Nauplius

Cyclopoid copepodit

Calanoid copepodit

$54 \pm 94 \quad 0.21$

$376 \pm 367 \quad 1.44$

*Paracyclops fimbriatus (Fischer, 1853)

*Canthocamptus microstaphylinus (Wolf, 1905)

${ }^{*}$ Canthocamptus staphylinus (Jurine, 1820)

Total Copepoda

$26104 \pm 7953100.00$ 
The most common species in the reservoir was Bosmina longirostris from Cladocera found in all sampling months. Besides, D. cucullata was sampled for ten months, $D$. longispina and $D$. pulex for nine months, and Chydorus sphaericus for seven months. The most common species from Copepoda were Arctodiaptomus wierzejskii found during eight months and Acanthocyclops robustus and Thermocyclops crassus found during seven months. Also, Cyclopoid copepodites, Calanoid copepodites and Nauplius from Copepoda were found in all sampling months. Moina micrura, Pleuroxus aduncus, Chydorus latus, Alona quadrangularis and Leydigia leydigi from Cladocera and Cyclops strenuus from Copepoda were sampled only in one month during the study. All the species determined are recorded for the first time in the Kayalıköy Reservoir. According to Ustaoğlu (2015) and Güher (2014), all the species recorded in the Kayalıköy Reservoir are widely distributed in Turkey.

As a result of the quantitative evaluation of planktonic microcrustacean samples, an average of $26586 \mathrm{ind} / \mathrm{m}^{3}$ Cladocera and 26014 ind. $/ \mathrm{m}^{3}$ Copepoda were found and the average value of planktonic microcrustacean in the reservoir was 52690 ind. $/ \mathrm{m}^{3}$ (Table 2). In other words, the planktonic microcrustaceans in the Kayalıköy Reservoir consists of $50 \%$ Cladocera and $50 \%$ Copepoda. However, a large part of Copepoda consists of larval individuals such as Nauplius or copepodite stage $(21 \%$ adult individuals, $79 \%$ larval individuals).

When the sampling months were evaluated based on average individual values per $\mathrm{m}^{3}$, the maximum number of Cladocera and Copepoda was found in October (111276 ind $\left./ \mathrm{m}^{3}\right)$ followed by May $\left(101636 \mathrm{ind} / \mathrm{m}^{3}\right)$ and the minimum was found in February (13004 ind $/ \mathrm{m}^{3}$ ) followed by December (14420 ind $/ \mathrm{m}^{3}$ ) (Figure 3). According to the results of cluster analysis, July, September, August, November, and June were the most similar to each other while the other similar months were January, February, December, and April (Figure 4).

The maximum number of Cladocera and Copepoda specimens were recorded at the 1 st station $\left(54853 \mathrm{ind} / \mathrm{m}^{3}\right)$ followed by the $2^{\text {nd }}$ and $3^{\text {rd }}$ stations with $53756 \mathrm{ind} / \mathrm{m}^{3}$ and $49642 \mathrm{ind} / \mathrm{m}^{3}$, respectively (Figure 5).

When the results were evaluated in terms of sampling months, the maximum organism number was found in autumn $\left(82680 \mathrm{ind} / \mathrm{m}^{3}\right)$, followed by spring $\left(60908 \mathrm{ind} / \mathrm{m}^{3}\right)$ and summer $\left(52042\right.$ ind. $\left./ \mathrm{m}^{3}\right)$ and the minimum was found in winter (15130 ind $/ \mathrm{m}^{3}$ ) (Figure 6). The results of the cluster analysis showed that spring with summer (92\% similarity) and summer with autumn ( $77 \%$ similarity) were very similar to each other apart from winter (Figure 7). The alteration of temperature affects the available nutrients in the environment, so it influences indirectly the abundances of zooplankton (Geller and Müller, 1981). In the present study, the lowest total the planktonic microcrustacean was determined in winter when the water temperature reached its lowest values.

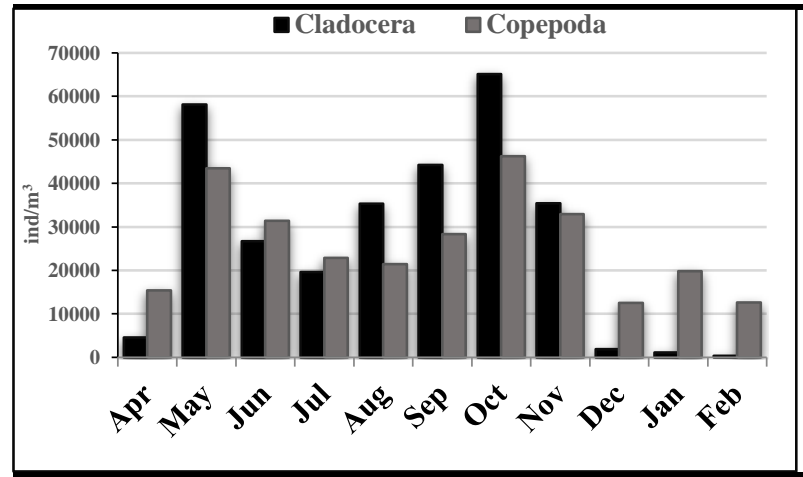

Figure 3. The abundance of planktonic microcrustacean in Kayalıköy Reservoir according to the sampling months

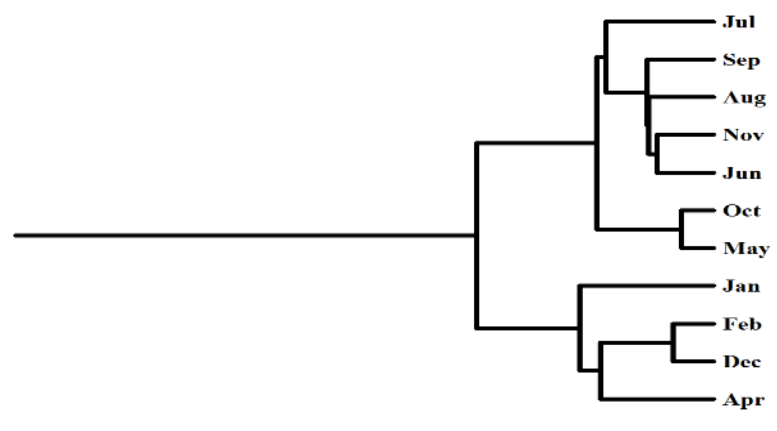

0, \% Similarity 50, 100

Figure 4. Cluster analysis showing the similarity index of planktonic microcrustacean according to the sampling months

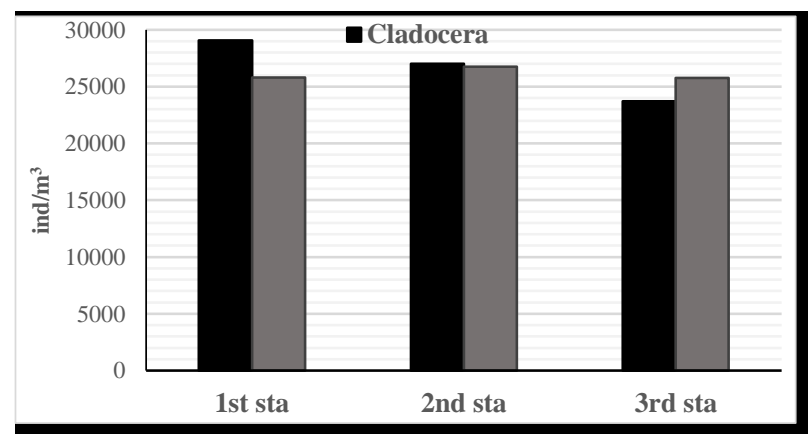

Figure 5. The abundance of planktonic microcrustacean in Kayalıköy Reservoir according to the sampling stations

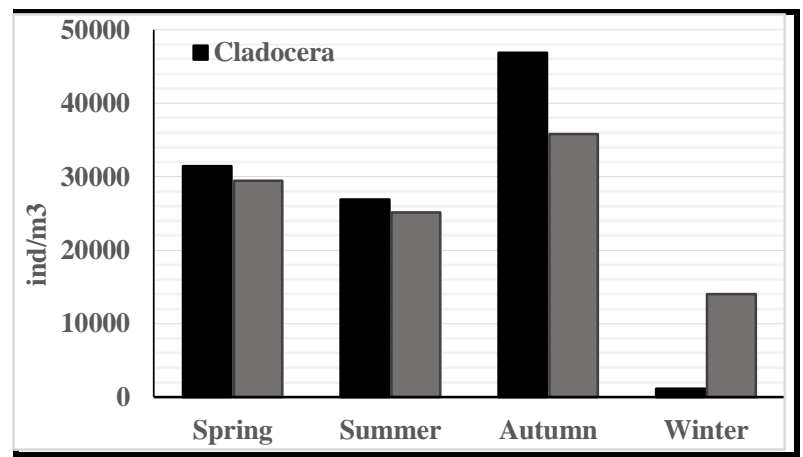

Figure 6. The abundance of planktonic microcrustacean in Kayalıköy Reservoir according to seasonal samples 


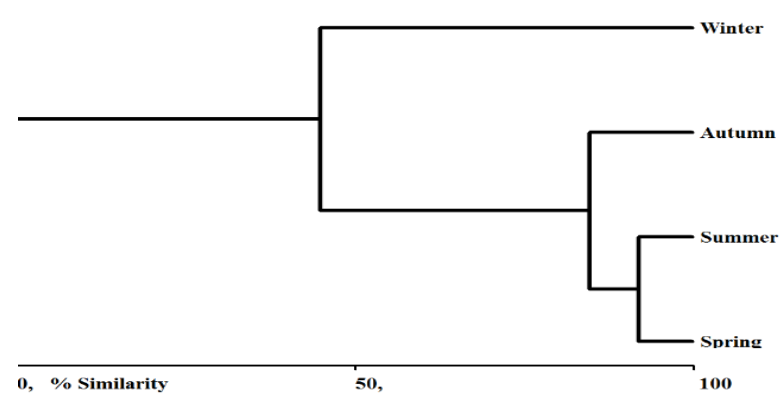

Figure 7. Cluster analysis showing the similarity index of planktonic microcrustacean according to seasonal samples

Monthly changes in species richness, diversity and maximum dominancy of microcrustacean are given in Table 3. According to the results of the Simpsons diversity, while species richness is the maximum (9.180) in May, it was found in its lowest value (1.936) in February. According to the Shannon diversity index, while species richness is the maximum (0.839) in June, it was found in the lowest value (0.431) in February. According to the Margalef index, no significant differences in species diversity were observed between the months $(p>0.005)$ (Table 3$)$

Spearman's correlation was used to determine the relationship of Cladocera and Copepoda groups with each other and with environmental parameters. Accordingly, a positive correlation was found between Copepoda and Cladocera groups $(r=0.891 \quad p<0.01)$. Positive significant correlations were found between Cladocera and light permeability ( $r=0.661)$, sulfate $(r=0.636)$ and $\mathrm{Chl}-\mathrm{a}(\mathrm{r}=0.682)$, while Copepoda was found to be positively correlated with light permeability $(r=0.697)$ and sulfate $(r=0.636)(p<0.05)$. There was also a positive correlation between dissolved oxygen and light permeability ( $r=0.753)$, sulfate $(r=0.866)$ and Chl-a $(r=0.907)(p<0.01)$ (Table 4).

Table 3. Species diversity and species richness values of microcrustacean groups according to the sampling months

\begin{tabular}{|c|c|c|c|c|c|c|c|c|c|c|c|}
\hline Index & Apr & May & Jun & Jul & Aug & Sep & Oct & Nov & Dec & Jan & Feb \\
\hline Shannon J' & 0.812 & 0.792 & 0.839 & 0.781 & 0.786 & 0.785 & 0.717 & 0.696 & 0.527 & 0.504 & 0.431 \\
\hline Simpsons Diversity (1/D) & 6.977 & 9.180 & 7.654 & 6.022 & 6.543 & 6.052 & 6.423 & 5.157 & 2.249 & 2.281 & 1.936 \\
\hline Margaleff M Base 10, & 7.673 & 6.591 & 6.926 & 7.129 & 6.942 & 6.789 & 6.539 & 6.826 & 7.935 & 7.636 & 8.021 \\
\hline
\end{tabular}

Table 4. According to the Spearman's correlation analysis, the relationship between microcrustacean groups and environmental parameters in Kayalıköy Reservoir (Cop: Copepoda, Cla: Cladocera)

\begin{tabular}{|c|c|c|c|c|c|c|c|c|c|c|c|c|c|}
\hline & Cla & Cop & DO & LP & $\mathrm{pH}$ & EC & $\mathrm{NO}_{2} \mathbf{N}$ & $\mathrm{NO}_{3} \mathrm{~N}$ & 0-PO & $\mathrm{SO}_{4}$ & Sal & $\mathrm{Cl}$ & Chl-a \\
\hline Cla & 1.000 & & & & & & & & & & & & \\
\hline Cop & $.891^{\star *}$ & 1.000 & & & & & & & & & & & \\
\hline DO & .524 & .415 & 1.000 & & & & & & & & & & \\
\hline LP & $.661^{*}$ & $.697^{\star}$ & $.753^{\text {** }}$ & 1.000 & & & & & & & & & \\
\hline $\mathrm{pH}$ & .269 & .082 & .370 & .221 & 1.000 & & & & & & & & \\
\hline $\mathrm{EC}$ & .155 & .064 & -.483 & -.191 & -.141 & 1.000 & & & & & & & \\
\hline $\mathrm{NO}_{2} \mathrm{~N}$ & .318 & .396 & $.644^{*}$ & $.822^{* *}$ & .122 & -.295 & 1.000 & & & & & & \\
\hline $\mathrm{NO}_{3} \mathrm{~N}$ & -.364 & -.109 & -.424 & .059 & -.146 & -.036 & .226 & 1.000 & & & & & \\
\hline $0-\mathrm{PO}_{4}$ & -.210 & -.024 & -.374 & .134 & -.218 & .024 & .111 & $.908^{* *}$ & 1.000 & & & & \\
\hline $\mathrm{SO}_{4}$ & $.636^{*}$ & $.636^{*}$ & $.866^{\text {t* }}$ & $.916^{* *}$ & .187 & -.409 & $.797^{\star *}$ & -.055 & -.005 & 1.000 & & & \\
\hline Sal & -.032 & -.174 & -.443 & -.422 & -.264 & $.851^{\star *}$ & -.480 & -.380 & -.291 & -.586 & 1.000 & & \\
\hline $\mathrm{Cl}$ & .362 & .404 & -.315 & -.005 & -.202 & .536 & .100 & -.019 & -.156 & -.099 & .383 & 1.000 & \\
\hline Chl-a & $.682^{*}$ & .545 & $.907^{\text {t* }}$ & $.620^{*}$ & .360 & -.409 & .396 & $-.655^{\star}$ & -.550 & $.727^{*}$ & -.293 & -.164 & 1.000 \\
\hline
\end{tabular}

** Correlation is significant at the 0.01 level

${ }^{*}$ Correlation is significant at the 0.05 level

When the results of this research were compared with the zooplankton data formerly reported in reservoirs, it is seen that different results were obtained in terms of Cladocera and Copepoda abundance and diversity depending on the characteristics of the sampled reservoirs. For instance, Yiğit and Altındağ (2005) reported 9 Cladocera (27.3\%) and 4 Copepoda $(15.8 \%)$ species in Hirfanlı Dam Lake, Dirican and Musul (2008) reported 7 Cladocera and 3 Copepoda species in the Çamlıgöze Reservoir, Bekleyen et al., (2009) reported 9 Cladocera $(27.3 \%)$ and 4 Copepoda $(15.8 \%)$ species in Dicle Reservoir, Saler and Aliş (2014) found 11 of Cladocera $(21.2 \%)$ and 7 of Copepoda (13.4 \%) species in Hancağız Dam Lake, Bekleyen et al., (2014) found 9 Cladocera (29.3 $\%)$ and 2 Copepoda (15.8\%) species in Kralkızı Dam Lake, Güher and Çolak (2015) found 11 Cladocera $(27 \%)$ and 6
Copepoda (14\%) species in Süleoğlu Dam Lake, Ulgu and Bozkurt (2015) found 10 Cladocera $(23.59 \%)$ and 8 Copepoda (8.57 \%) species in Tahtaköprü Dam Lake. Saler et al., (2017) reported 13 Cladocera $(39.4 \%)$ and 3 Copepoda $(9.1 \%$ ) species in Boztepe Recai Kutan Reservoir and Güher (2019) found 19 Cladocera $(66 \%)$ and 8 Copepoda (34\%) species in Kadıköy Dam Lake.

Although Rotifera is the dominant group among the zooplanktonic organisms in freshwater ecosystems, Cladocera is a qualitatively and quantitatively dominant group among the planktonic microcrustaceans (Saksena, 1987; Rocha et al., 1999). In the present study, a total of 40 taxa, (24 Cladocera (50\%) and 16 Copepoda $21 \%$ adult 
individuals and $79 \%$ larval individuals) were identified in Kayalıköy Reservoir and Cladocera was found as the dominant group among the planktonic microcrustaceans.

Zooplanktonic organisms play an important role as an indicator in determining water quality, eutrophication, and water pollution level. Especially, Cladocera and Cyclopoid copepods are well adapted to eutrophic conditions (Gannon and Stemberger, 1978). It was reported by Bozkurt and Akın (2012) that Bosmina longirostris, Coronatella rectangula, Acanthocyclops robustus, and Cyclops vicinus were known as the indicator species of eutrophication. Also, Yağcı (2016) reported that Ceriodaphnia quadrangula, B. Iongirostris, Chydorus sphaericus, Daphnia longispina and Cyclops strenuus paternonis species are mesotrophic-eutrophic indicators. In the present study, D. longispina, $C$. qaudrangula, B. longirostris, C. rectangula, C. sphaericus from Cladocera; A. robustus, $C$. vicinus and $C$. strenuus from Copepoda were the most common species.

In a eutrophic lake, annual mean chlorophyll-a is 225 $\mathrm{mg} / \mathrm{m}^{3}$ and Cladocera is 160000 ind. $/ \mathrm{m}^{3}$ (Vijverberg and Boersma, 1997). The chlorophyll-a in a meso-oligotrophic lake was $8.7 \mathrm{mg} / \mathrm{m}^{3}$, and the average zooplankton was 2355 ind. $/ \mathrm{m}^{3}$ (Ostojic, 2000). According to these results that Kayalıköy Reservoir has been concluded as having a mesotrophic character in terms of the mean zooplankton (52690 ind./m³) and chlorophyll-a (10.71 ug/L) content.

\section{REFERENCES}

Anonymous. (2015). Yüzeysel Su Kalitesi Yönetimi Yönetmeliğinde Değişiklik Yapılmasına Dair Yönetmelik. Resmi Gazete, 15 Nisan 2015, Çarşamba, Sayı: 29327.

Apostolov, A.M. \& Marinov, T.M. (1988). Fauna Bulcarica 18, Copepoda, Harpacticoida. In Aedibus Academiae Scientiarum 18, Bulcaricae, Sofia.

Bekleyen, A., Gökot, B. \& Varol, M. (2009). Dicle baraj gölü'nün (Diyarbakır) zooplanktonu. Ulusal Su Günleri Sempozyumu 29 Eylül-1 Ekim 2009, (s.10). Elazığ, Türkiye.

Bekleyen, A., Gökot, B. \& Varol, M. (2014). Kralkızı baraj gölü'nün (Diyarbakır) zooplanktonu. 5. Doğu Anadolu Bölgesi Su ürünleri Sempozyumu, 31 Mayıs-2 Haziran 2014 (s.322-323). Elazığ. Türkiye.

Berzins, B. \& Pejler, B. (1987). Rotifer occurrence in relation to $\mathrm{pH}$. Hydrobiologia, 147: 107-116.

Bledzki, L.A. \& Raybok, J.J. (2016). Freshwater crustacean zooplankton of Europe. Springer International Publishing Switzerland. DOI: 10.1007/978-3-319-29871-9_12

Bozkurt, A. \& Akın, Ş. (2012). Zooplankton fauna of Yeşilırmak (between Tokat and Blacksea), Hasan Uğurlu and Suat Uğurlu Dam Lakes. Turkish Journal of Fisheries and Aquatic Sciences, 12: 777-786.

Dirican, S. \& Musul, H. (2008). Çamlıgöze baraj gölü (Sivas-Türkiye) zooplankton faunası üzerine bir çalışma. SAÜ, Fen Bilimleri Dergisi, 12(1), 17-21.

Dorak, Z., Köker, L., Gaygusuz, Ö. Gürevin, C., Akçaalan, R. \& Albay, M. (2019). Zooplankton biodiversity in reservoirs of different geographical regions of Turkey: Composition and distribution related with some environmental conditions. Aquatic Sciences and Engineering, 34(1), 2938. DOI: 10.26650/ASE2019522326

\section{CONCLUSION}

In conclusion, a total of 40 taxa consisting of 24 Cladocera and 16 Copepoda were identified in the Kayalıköy Reservoir. In terms of the species diversity, the richest months were September and May with 19 species followed by April, June, and November with 13 species. The most common species in the reservoir were Daphnia cucullata, $D$. longispina, D. pulex, Bosmina longirostris and Chydorus sphaericus from Cladocera and Arctodiaptomus wierzejskii, Acanthocyclops robustus and Thermocyclops crassus from Copepoda. As a result of quantitative evaluation of microcrustacean samples, $50 \%$ of the total microcrustacean was Cladocera $\left(26586\right.$ ind $\left./ \mathrm{m}^{3}\right)$ and $50 \%$ was Copepoda (26014 ind $\left./ \mathrm{m}^{3}\right)$. However, a large part of Copepoda consisted of Nauplius or copepodite stage (21\% adult individuals, $79 \%$ larval individuals). The maximum number of Cladocera and Copepoda was observed in October $\left(111276 \mathrm{ind} / \mathrm{m}^{3}\right)$, at the 1 st station $\left(54853 \mathrm{ind} / \mathrm{m}^{3}\right)$ and autumn $\left(82680 \mathrm{ind} / \mathrm{m}^{3}\right)$. The comparison of the results of physicochemical analyses with the National Standard for Turkish inland water revealed that water temperature, dissolved oxygen, $\mathrm{pH}$, sulfate, salinity, and chloride values indicated the first quality level, while light permeability, nitrite-nitrogen, nitrate-nitrogen, phosphate, and chlorophyll-a values indicate the second and the third quality levels (Anonymous, 2015). According to these results, Kayalıköy Reservoir was concluded to have a mesotrophic character in terms of microcrustacean fauna and the physicochemical parameters.

\section{ACKNOWLEDGEMENTS}

This research has been supported by TÜBAP-2018/66 project.

Dussart, B. (1967). Les Copepodes des eaux continentales d'Europe occidentale, Tome I, Calanoides et Harpacticoides. N. Boubee et Cie, Paris.

Dussart, B. (1969). Les Copepodes des eaux continentales d'Europe occidentale, Tome II. Cyclopoides et Biologie, N. Boubee et Cie, Paris.

Dussart, B. \& Defaye, D. (2002). Word directory of Cladocera Copepoda of inland waters I-Calaniformes. Backhuys Publishers Leiden, the Netherlands.

Dussart, B. \& Defaye, D. (2006). Word directory of Cladocera Copepoda of inland waters II-Cyclopiformes. Backhuys Publishers Leiden, the Netherlands.

EPA, (2001). Method 200.7: Determination of Metals and Trace Elements in Water and Wastes by Inductively Coupled Plasma-Atomic Emission Spectrometry, U.S. Environmental Protection Agency.

Flössner, D. (1972). Krebstiere Crustacea kiemen und blattfussar Brachiopoda fischlause, Branchiura. Tierwelt-Deusch.60 Veb. Gustav Fischer Verlag, Jena, 105-161.

Gannon, J. E. \& Stemberger, R. S. (1978). Zooplankton especially crustaceans and rotifers as indicators of water quality. Transactions of the American Microscopical Society, 97, 16-35.

Geller, W. \& Müller, H. (1981). The filtration apparatus of Cladocera: Filter mesh-sizes and their implications on food selectivity. Oceanologia, 49: 316-321.

Güher, H. \& Çolak, Ş. (2015). Süloğlu baraj gölünün (Edirne) zooplankton (Rotifera, Cladocera, Copepoda) faunası ve mevsimsel değişimi. Trakya University Journal of Natural Sciences, 16 (1), 17-24. 
Güher, H. (2014). A Checklist for zooplankton (Rotifera, Copepoda, Cladocera) of European Turkey inland waters. Ege Fisheries and Aquatic Sciences, 31(4), 221-225. DOI: 10.12714/egejfas.2014.31.4.08

Güher, H. (2019). Seasonal variation in planktonic microcrustacea (Copepoda, Cladocera) diversity in Kadiköy Reservoir (Edirne/Turkey). Acta Aquatica Turcica, 15(2), 188-196. DOI:10.22392/actaquatr.484963

Jaccard, P. (1912). The distribution of the flora of the alpine zone. New Phytologist, 11, 37-50.

Kaya, M. \& Altındağ, A. (2007). Zooplankton fauna and seasonal changes of Gelingüllü dam lake (Yozgat, Turkey). Turkish Journal of Zoology, 31, 347-351.

Kiefer, F. (1978). Das Zooplankton der Binnengewasser 2. Teil. Stuttgart.

Korinek, V. (1987). Revision of three species of the genus Diaphanosoma Ficher, 1850. Hidrobiologia, 145, 35-45.

Krebs, C.J. (1999). Ecological Methodology. Addison Wesley Longman, Inc., Menlo Park, California.

Lackey, J.B. (1938). The manipulation and counting of river of river plankton and changes in some organisms due to formalin preservation. Public Health Reports, 53, 2080-2093.

Margalef, R. (1958). Information theory in ecology. General Systems, 3, 3671.

Margaritora, F. (1983). Cladocerı (Crustacea: Cladocera). Inst. di. Zoologia, dell Univ. Roma.

OECD, (1982). Eutrophication of waters: monitoring, assessment and control. Organization for Economic Co-Operation and Development, Paris.

Ostojic, A. (2000). Effect of eutrophication on changes in the composition of zooplankton in the Grosnica reservoir (Serbia, Yugoslavia). Hydrobiologia, 436, 171-178.

Parmar, T.K., Rawtani, D. \& Agrawal, Y.K. (2016). Bioindicators: the natural indicator of environmental pollution. Frontiers in Life Science, 9(2), 110118. DOI: $10.1080 / 21553769.2016 .1162753$

Patra, A., Santra, K.B. \& Manna, C.K. (2011). Ecology and diversity of zooplankton in relation to physicochemical characteristics of water of Santragachi Jheel, West Bengal. India. Journal of Wetlands Ecology, 5 , 20-39.
Rocha, O., Matsumura-Tundisi, T., Espindola, E.L.G., Roche, K.F. \& Rietzler, A.C. (1999). Ecological theory applied to reservoir zooplankton. p. 2951. In: Theoretical Reservoir Ecology and its Applications (Ed. J.G. Tundisi, and M. Straskraba), International Institute of Ecology, Brazilian Academy of Sciences. Backhuys Publishers, Leiden, Holland.

Ryding, S.O. \& Rast, W. (1989). The control of eutrophication of lakes and reservoirs. Man and the Biosphere Series, Volume I, the Parthenon Puplishing Group, 314 p.

Saksena, N.D. (1987). Rotifer as indicators of water quality. Acta Hydrochimica Hydrobiologica, 15, 481-485.

Saler, S. \& Alış, N. (2014). Zooplankton of Hancağız dam lake (GaziantepTurkey). Journal of Survey in Fisheries Sciences, 1(1), 36-45.

Saler, S., Alpaslan, K., Karakaya, G. \& Gündüz, F. (2017). Zooplankton of Boztepe Recai Kutan dam lake (Malatya -Turkey). Ege Journal of Fisheries and Aquatic Sciences, 34(3), 261-267. DOI:10.12714/egejfas.2017.34.3.03

Shannon, C.E. \& Weaver, W. (1949). The Mathematical theory of communication, University of Illinois Press, Urbana, $117 \mathrm{pp}$.

Smirnov, N.N. (1974). Fauna of USSR. Crustacea, Chydoridae. Vol.I, No: 2, $629 \mathrm{p}$.

Thomann, R.V. \& Mueller, J.A. (1987). Principle of surface water quality modelling and control. Harper and Row Publishers, New York. 644 p.

Ulgu, M. \& Bozkurt, A. (2015). Zooplankton fauna of Tahtaköprü dam lake (Gaziantep). International Journal of Scientific and Technological Research, 1(1), 202-215.

Ustaoğlu, M.R. (2015). An updated zooplankton biodiversity of Turkish inland waters. Journal of Limnology and Freshwater Fisheries Research, 1(3), 151-159. DOI: 10.17216/LimnoFish-5000151941

Vijverberg, J. \& Boersma, M. (1997). Long term dynamics of small-bodied and large-bodied Cladocerans durind the eutrophication of a shallow reservoir, with special attennion for Chydorus sphaericus. Hydrobiologia, $360,233-242$

Yağcl, M. A. (2016). Variations in the zooplankton species structure of eutrophic lakes in Turkey. Lake Sciences and Climate Change, 81

Yiğit, S. \& Altındağ, A. (2005). A taxonomical study on the zooplankton fauna of Hirfanlı dam lake (Kırşehir), Turkey. Gazi Üniversitesi Fen Bilimleri Dergisi, 18(4), 563-567. 